DOI: https://doi.org/10.35961/jppmkepri.v1i2.198

\title{
Pemanfaatan Teknologi Informasi Sebagai Media Edukasi Pencegahan Penularan Covid-19, Media Pemasaran, dan Media Pembelajaran Pada Masyarakat Kelurahan Sei Jang, Kota Tanjungpinang
}

\author{
Muhammad Alfan Sidik ${ }^{1 *}$, Desi Nurmawati ${ }^{2}$, Rana Azhara Siregar ${ }^{3}$, Syaiful Anam $^{4}$, Sanisah $^{5}$, Imam \\ Nur Alip ${ }^{6}$, Erlangga War Saputra ${ }^{7}$, Dandi ${ }^{8}$, Muhammad Kurnia Hafis ${ }^{9}$,Muhammad Rizki ${ }^{10}$ \\ 1, 2, 3, 4, 5, 6, 7, 8, 9, 10 STAIN Sultan Abdurrahman Kepulauan Riau, Bintan, Kepulauan Riau, 29123, Indonesia \\ *muhammad_alfan@stainkepri.ac.id
}

\begin{abstract}
Abstrak
Sebagai bagian dari masyarakat Kepulauan Riau yang terdampak dari Covid-19, yang telah memunculkan banyak permasalahan di masyarakat. Sebagai respon, P3M STAIN Sultan Abdurrahman Kepulauan Riau, melaksanakan KKN Pandemi Covid-19, pelaksanaan kegiatan pengabdian ini berupa KKN-DR (Dari Rumah) dan KKN-KS (Kerja Sosial). Tim Penulis pengabdian merupakan, bagian dari peserta pelaksanaan kegiatan PKM berupa KKN ini. Lokasi adalah di wilayah Kelurahan Sei Jang, terutama di RT 03/RW 02, dan beberapa di daerah Perumahan Air Raja. Kelurahan Sei Janng merupakan bagian dari pusat kota, yang aktivitas warga masyarakat masih cenderung ramai dan padat, hal ini merupakan sesuatu yang rawan dengan bahaya penularan Covid-19, oleh karena itu perlu dilakukan beberapa kegiatan pengabdian kepada masyarakat. Adapun kegiatan yang dilaksanakan adalah pemanfaatan teknologi informasi (media sosial) dalam menanggulangi permasalahan karena Covid-19, yang meliputi 4 fokus tema kegiatan: Pertama: Pendataan penduduk, Kedua, Pemasaran produk melalui Platform Digital, ketiga, Edukasi Pencegahan Penularan Covid-19 dan Keempat, Pembelajaran Agama melalui daring. Kegiatan pengabdian ini dilaksanakan menggunakan metode: ABCD dan PAR. Tulisan ini membahas tentang analisis dari pelaksanaan kegiatan tersebut.
\end{abstract}

Kata kunci: Covid-19; dampak; Sei Jang; pemanfaatan; teknologi; KKN.

\begin{abstract}
As part of the Riau Islands community who are affected by COVID-19, which has raised many problems in the community. As a response, P3M STAIN Sultan Abdurrahman Riau Islands, carried out the Covid-19 Pandemic Community Service Program, the implementation of these service activities in the form of $K K N$ - DR (From Home) and KKN-KS (Social Work). The dedication writing team
\end{abstract}


is part of the participants in the implementation of PKM activities in the form of this KKN. The location is in the Sei Jang Kelurahan area, especially at RT 03 / RW 02, and some in the Air Raja Housing area. Kelurahan Sei Janng is part of the city center, where the activities of community members still tend to be crowded and crowded, this is something that is prone to the danger of Covid-19 transmission, therefore it is necessary to carry out several community service activities. The activities carried out are the use of information technology (social media) in overcoming problems due to Covid-19, which includes 4 focus theme activities: First: Population Data Collection, Second, Product Marketing through Digital Platforms, third, Covid-19 Transmission Prevention Education and Fourth, Religion Learning through online. This service activity was carried out using the following methods: ABCD and PAR. This paper discusses the analysis of the implementation of these activities.

Keywords: Covid-19, impact, Sei Jang, utilization, technology, KKN.

\section{Pendahuluan}

Corona Virus atau lebih dikenal sebagai Covid 19, telah menjadi pandemi dunia, setelah ditetapkan oleh Organisasi Kesehatan Dunia (WHO) sebagai wabah dunia. Virus yang bermula dari daerah Wuhan, Ibukota Hubei, Republik Rakyat Tiongkok ini telah menyebar ke seluruh dunia hingga saat ini (Suppawittaya. P., Pakara. Y., and Pratchayapong. Y., 2020). Di Indonesia sendiri hingga saat ini jumlah kasus masih terus bertambah, meskipun tingkat kematian akibat dari Covid- 19 ini semakin menurun.

Berbagai kebijakan telah dilakukan oleh Pemerintah dalam penanggulangan pandemi Covid-19 ini, mulai dengan diberlakukannya PSBB (Pembatasan Sosial Berskala Besar) dengan berbagai ketentuan yang mengikat, seperti pembatasan semua kegiatan sosial yang mengundang kerumunan, pendidikan diganti dengan pembelajaran melalui daring, dalam dunia kerja diberlakukannya anjuran Work From Home (WFH), dalam kegiatan peribadatan di tempat-tempat ibadah juga dibatasi, dan semua pembatasan kegiatan lainnya yang dapat mengakibatkan penularan virus Covid-19 (Kemenkes, 2020), meskipun saat ini pembatasan tersebut sudah dilonggarkan dengan istilah New Normal, artinya beberapa kegiatan sosial dapat dijalankan asalkan dengan menerapkan protokol kesehatan yang ketat seperti: menjaga kebersihan, pola hidup sehat, mengunakan masker, rajin mencuci tangan, social distancing (jaga jarak sosial), dan physical distancing (jaga jarak fisik).

Pembatasan ini meskipun sudah memasuki new normal, masih tetap menimbulkan banyak dampak bagi masyarakat, salah satu yang paling dominan adalah pada ekonomi masyarakat. Terjadi krisis ekonomi di hampir semua kalangan masyarakat, salah satunya adalah para pelaku usaha kecil yang usahanya mengandalkan dari keramaian sosial, cenderung berdampak buruk pada ekonomi. Bahkan mempertaruhkan kesehatan diri mereka demi keberlangsungan ekonomi keluarga, apabila tetap berjualan sedangkan Covid- 19 ini masih terus menyebar (WHO, 2020).

Dampak sosial dan ekonomi karena merebaknya Covid-19 yang telah berlangsung di kalangan masyarakat terutama para pelaku usaha kecil, membuat kita sebagai sesama warga negara Indonesia merasa terenyuh dan berempati, untuk melaksanakan kegiatan pengabdian yang dapat memberikan bantuan terhadap masyarakat yang berdampak secara ekonomi (Kementerian Keuangan RI, 2020).

Kota Tanjung Pinang merupakan ibu kota provinsi Kepulauan Riau, merupakan daerah yang juga ikut terdampak Covid-19 ini, status wilayahnya masih zona merah, dan angka yang terinfeksi positif virus ini, masih bertambah, bahkan Wali Kota Tanjungpinang, Syahrul meninggal pada 28 april 2020 karena 
Covid-19. Penyebaran virus di kota Tanjung Pinang ini, pertama kali berasal dari Kelurahan Sei Jang, pada maret 2020 (liputan6.com, en), dan hingga saat ini masih bertambah beberapa pasien positif dari kelurahan ini (zonakepri.com, en). Artinya bahwa penanganan kasus di Kelurahan Sei Jang perlu mendapatkan perhatian, dan sebagai daerah yang juga ramai interaksi sosial karena termasuk ke dalam pusat perkotaan.

Pengabdian kepada masyarakat yang telah dilasanakan oleh mahasiswa-mahasiwa peserta KKN (Kuliah Kerja Nyata) STAIN Sultan Abdurrahman Kepulauan Riau ini mengambil lokasi pengabdian di Kelurahan Sei Jang, terutama di RT 03/RW 02, dan beberapa wilayah lainnya. Pelaksanaan kegiatan KKN STAIN Sultan Abdurrahman Kepulauan Riau, pada kesempatan ini mengusung tema "Upaya Penguatan Pemberdayaan Ekonomi Masyarakat, Pencegahan Penularan Covid-19 dan Penguatan Kapasitas Masyarakat Dalam Menanggulangi Dampak Covid-19”. Pelaksanaan Kegiatan KKN dapat dilaksanakan dengan dengan dua kategori KKN. Pertama, KKN-DR (Kuliah Kerja Nyata dari Rumah), yakni merupakan KKN yang dilaksanakan selama masa pandemi, dengan cara melakukan upaya penguatan pemberdayaan ekonomi masyarakat, penguatan atas kesadaran kepedulian masyarakat terhadap pencegahan penularan Covid-19 serta penguatan kapasitas masyarakat dalam menanggulangi dampak wabah Covid-19 dilakukan dari rumah, dengan mengunakan berbagai platform digital.

Kedua, KKN-KS (Kulah Kerja Nyata Kerja Sosial), merupakan KKN yang dilaksanakan selama masa pandemi, dengan cara melakukan upaya penguatan pemberdayaan ekonomi masyarakat, penguatan atas kesadaran kepedulian masyarakat terhadap pencegahan penularan Covid-19 serta penguatan kapasitas masyarakat dalam menanggulangi dampak wabah Covid-19, melalui keterlibatan langsung di wilayah mahasiswa tinggal, bekerja sama dengan berbagai lembaga dengan tugas resmi, di bawah kendali dan pengawasan pihak berwenang serta mengikuti protokol kesehatan yang ditetapkan oleh pemerintah.

Pelaksanaan kegiatan pengabdian yang berupa KKN ini baik berupa KKN-DR maupun KKN-KS, akan dilaksanakan dalam fokus 4 tema kegiatan: Pertama: Pendataan Penduduk, Kedua, Pemasaran produk melalui Platform Digital, ketiga, Edukasi Pencegahan Penularan Covid-19 dan Keempat, Pembelajaran Agama melalui daring.

\section{Metode}

Metodologi pengabdian yang digunakan dalam kegiatan KKN ini, setidaknya berupa dua metode, metode Participatory Action Research (PAR) dan metode ABCD atau Asset Based Community Development. Metode PAR, peserta Tim pengabdian sebagai fasilitator masyarakat pada dasarnya berperan dalam pengembangan pembelajaran masyarakat lokal untuk membangun tingkat kemandirian dalam menyelesaikan masalah yang mereka hadapi. Bersamaan dengan itu, membangun kesadaran kritis masyarakat terhadap berbagai format ekonomi politik yang berlangsung secara mapan dibarengi dengan memperkuat kemampuan masyarakat untuk berdialog sehingga memiliki bargaining position yang kuat dengan kekuatan lain. Maka dari itu diperlukan beberapa strategi sebagai berikut:

a) Riset Pendahuluan, sebelum upaya get in dalam kawasan Kelurahan Sei Jang terutama di RT 03/RW 02 dan tempat lainnya, peserta KKN melakukan riset pendahuluan sebagai penjajakan awal. Dalam riset ini peserta KKN melakukan observasi aktivitas sehari-hari masyarakat dampingan, lingkungan sosial tempat anak-anak berkumpul, prilaku dan kebiasaan masyarakat, sanitasi, struktur masyarakat, dan yang terpenting adalah mengendus masalah.

b) Inkulturasi, langkah selanjutnya adalah inkulturasi, atau melebur dan membaur dalam kehidupan masyarakat sehari-hari. Informasi awal yang telah didapat ketika melakukan riset pendahuluan dijadikan pijakan untuk mengadaptasi diri di tengah kehidupan masyarakat. Langkah ini, peserta KKN akan melakukan proses pendekatan sebagai upaya trust building. Maka dari itu, peneliti akan berusaha untuk bersikap netral, khususnya dalam hal kepentingan golongan dan partai tertentu. 
c) Pengorganisasian Masyarakat, setelah tahap inkulturasi, peserta KKN akan membangun kelompok yang solid dan semacam local hero, terutama pada level grass root. Tujuan dari kelompok ini adalah dapat merumuskan masalah bersama.

d) Perencanaan Tindakan Aksi untuk Perubahan Sosial, setelah terumuskan masalah kemudian ditentukan rencana aksi melalui FGD, sekaligus menyusun strategi gerakan. Supaya aksi yang akan dilaksanakan menjadi sistematis dan terarah.

e) Aksi, pengimplementasikan rencana aksi dilaksanakan secara simultan dan partisipatif. Pemecahan persoalan kemanusiaan bukanlah sekerdar untuk menyelesaikan persoalan itu sendiri, tetapi merupakan proses pembelajaran masyarakat, sehingga terbangun pranata baru dalam komunitas dan sekaligus memunculkan community organizer dan mengakibatkan munculnya local leader yang menjadi agen perubahan.

f) Evaluasi, evaluasi dilakukan dengan melakukan kroscek kesesuaian kegiatan yang telah dilaksanakan dengan jalur dan arah yang ditentukan, serta impresi dan efek yang dihasilkan. Apabila langkah yang dilakukan justru berimplikasi negatif dan destruktif, maka bukan tidak mungkin peserta KKN akan merubah kegiatan, karena dalam PAR menghendaki pendekatan yang fleksibel dan multi dimensional untuk menunjang progresifitas masyarakat.

g) Refleksi, berdasarkan hasil evaluasi, proses pemberdayaan masyarakat dan program aksi yang terlaksana, peserta KKN bersama masyarakat melakukan refleksi semua proses dan hasil yang diperoleh. Resfleksi teoritis dirumuskan secara bersama, sehingga menjadi sebuah teori akademik yang dapat dipresentasikan pada khalayak publik.

PAR merupakan metode pengabdian yang berbasis penelitian yang dilaksanakan secara partisipatif di antara masyarakat dan pelaku ekonomi yang terkena dampak wabah COVID-19 terutama Pelaku UMKM di Sei Jang, Tanjung Pinang. Kegiatan pengabdian kepada masyarakat kali ini akan mendorong terjadinya aksi- aksi transformatif dalam melakukan tindakan ekonomi dan pencegahan dari dampak wabah tersebut.

Di dalam kegiatan Pengabdian Kepada Masyarakat dengan metode PAR, peserta tim pengabdian akan get in dalam kegiatan analisis permasalahan yang dihadapi, kemudian membuat proposal rencana kegiatan dan dilanjutkan dengan aksi partisipatif bersama warga masyarakat dalam melaksankan kegiatan yang telah direncanakan, namun dengan tetap mengedepankan social distancing (jaga jarak) dan menggunakan alat pelindung diri (APD).

Metode yang kedua adalah ABCD atau Asset Based Community Development, pendampingan ini mengutamakan pemanfaatan aset dan potensi yang ada disekitar dan dimiliki oleh pemuda atau komunitas masyarakat. Dalam metode ABCD memiliki 5 langkah kunci untuk melakukan proses kegiatan KKN ini:

Discovery (menemukan), Proses menemukan kembalik kesuksesan dilakukan melalui proses wawancara dan harus menjadi penemuan personal tentang apa yang menjadi kontribusi individu yang memberi hidup bagi sesbuah kegiatan. Pada tahap ini, peserta KKN mulai memindahkan tanggungjawab untuk perubahan kepada para individu yang berkepentingan dengan perubahan tersebut yaitu entitas lokal.

Dream (impian), Setelah melakukan wawancara kepada masyarakat, peserta KKN mulai mengetahui impian atau keinginan masyarakat Sei Jang. Setelah mengetahui keinginan atau impian maka langkahselanjutnya yaitu merancang sebuaah kegiatan untuk memenuhi impian masyarakat.

Design (Merancang), Proses merencanakan ini merupakan proses cara mengetahui aset-aset yang ada pada masyarakat. beberapa aset yang terlihat di wilayah masyarakat Sei Jang, salah satunya adalah media pemasaran melalui online, yang cakupanya bisa lebih luas. Aset ini yang akan dimanfaatkan untuk memenuhi impian masyarakat Sei Jang. 
Define (menentukan), Peserta KKN menentukan "pilihan topik positif" tujuan dari proses pencarian atau deskripsi mengenahi perubahan yang diinginkan. Penentuan ini akan dilakukan melalui FGD. Fokus pembahasan yang akan dibahas adalah hal-hal yang terkait dengan penentuan fokus permasalahan dan sekaligus perencanaan kegiatan.

Destiny (Lakukan), Peserta KKN akan melaksanakan serangkaian tindakan inspiratif yang mendukungproses kegiatan KKN ini. Langkah yang dilakukan dengan mengutamakan pemanfaatan aset dan potensi yang ada disekitar dan dimiliki oleh masyarakat. untuk kemudian digunakan sebagai bahan yang memberdayakan masyarakat itu sendiri.

\section{Hasil dan Pembahasan}

Jenis KKN yang dipilih oleh peserta Tim Kelompok pengabdian ini adalah KKN-KS (Kerja Sosial) dan juga KKN-DR (Dari Rumah), dengan mengangkat tema pendidikan pencegahan penularan, Peningkatan Ekonomi, Pendataan dan Keagamaan. Peserta Tim KKN ini terdiri dari 9 peserta dengan nama Tim Kelompok Ungu, yang berasal dari berbagai macam Program Studi seperti Ilmu al-Qur'an dan Tafsir, Manajemen Pendidikan Islam, Hukum Ekonomi Syari'ah, dan Hukum Keluarga Islam. Metode pengabdian yang digunakan juga beragam yaitu menggunakan metode ABCD dan juga Metode PAR (Participatory Action Research).

Pelaksanaan kegiatan KKN Kelompok Unggu, terbagi menjadi beberapa tahapan, tahapan pertama yaitu Persiapan, Pelaksanaan dan Pelaporan.

Pada tahapan persiapan, peserta KKN melakukan survey mengumpulkan informasi tentang kondisi dari lokasi KKN yaitu Kelurahan Sei Jang terutama di RT 03/RW 02 dan tempat lainnya, sesuai yang akan menjadi mitra dampingan, setelah ditemukan permasalahan, Peserta membuat rancangan kegiatan pelaksanan KKN yang sesuai dengan kebutuhan mitra dampingan.

Pada tahapan pelaksanaan, peserta KKN melaksanakan kegiatan yang telah dirancang, dengan menggunakan metode yang berbeda-beda sesuai dengan permasalahan yang dihadapi. Apabila peserta memilih KKN jenis KS, maka mereka mulai melaksanakan kegiatannya, misalnya:

Pada tahapan pelaporan, peserta KKN membuat laporan kegiatan KKN, kemudian mempresentasikan laporanya, dan mendokumentasikan laporannya dalam bentuk output kegiatan seperti, bookchapter dan jurnal ilmiah.

\section{Profil Kelurahan Sei Jang}

Secara tata letak geografis, lokasi KKN akan fokuskan di Gang Pulau Pandang, yang masuk dari persimpangan jalan Raja H. Fisabililah, di RT 03 RW 02, Kelurahan Sei Jang Kecamatan Tanjungpinang Timur. Jumlah penduduk sekitar 127 Kepala Keluarga. Trend mobilitas masyarakat di masa pandemi mengalami perubahan karena adanya pemberlakuan Social Distancing, masyarakat cenderung melaksanakan kegiatan di dalam rumah salah satunya adalah melakukan aktivitas budidaya tanaman hias.

Profil masyarakat pada lokasi KKN ini, banyak para pekerja formal, seperti pegawai dan pekerja kantoran. Bentuk interaksi sosial di lokasi KKN berupa Interaksi Asosiatif seperi toleransi, gotong royong, terjadinya akomodasi dan asimilasi. Secara Demografi, Nama Kelurahan ini diambil dari nama Sei Jang atau Sungai Jang, sebuah sungai yang melintasi kelurahan ini. Jumlah penduduk di lingkungan RT 03 ini tidak terlalu banyak dibandingkan RT yang lainnya. Secara Keagamaan, Aliran dan kepercayaan pada lokasi KKN ini adalah mayoritas penduduknya beragama Islam 98\% dan Buddha 2\%. Secara Ekonomi, terdapat banyak 
usaha dan produksi rumahan. Dari sisi Potensi Sosial Budaya, yang terdapat di daerah ini berupa kegiatan di setiap hari-hari besar saling toleransi beragama dan saling menghargai serta menghormati. Segi Potensi Pendidikan, menunjukkan salah satu bentuk kegiatan pendidikan masyarakat yaitu bersekolah (namun kegiatan tersebut dialihkan kepada bentuk daring dan dirumahkan selama pandemi). Potensi Kesehatan, Tidakan-tindakan adaptif yang dilakukan komunitas sebagai upaya pencegahan dan pengendalian penyebaran Covid-19 dengan melaksanakan social distancing, menonaktifkan kegiatan sosial masyarakat, mengikuti protokol kesehatan, meningkatkan daya tubuh. Ketersediaan sarana dan prasarana kesehatan di wilayah ini terdapat 1 Klinik Kesehatan dan 1 Apotek.

Jumlah penduduk di RT 03/RW 02 Sei. Jang Kota Tanjungpinang adalah 508 dengan total KK sebanyak 127 KK. Di RT 03/RW 02 ini ada 167 jiwa dengan jenis kelamin laki-laki, dan 341 jiwa berjenis kelamin perempuan. Berikut tabel jumlah penduduk di RT 03/RW 02 Sei. Jang Kota Tanjungpinang:

Tabel 1

Jumlah Penduduk Berdasarkan Usia

\begin{tabular}{|c|c|c|c|}
\hline No & Usia (Tahun) & Laki- laki (Jiwa) & Perempuan (Jiwa) \\
\hline 1 & $<5$ & 3 & 8 \\
\hline 2 & $6-10$ & 13 & 24 \\
\hline 3 & $11-15$ & 12 & 31 \\
\hline 4 & $16-20$ & 19 & 32 \\
\hline 5 & $21-25$ & 16 & 36 \\
\hline 6 & $26-30$ & 13 & 29 \\
\hline 7 & $31-35$ & 19 & 33 \\
\hline 8 & $36-40$ & 18 & 26 \\
\hline 9 & $41-45$ & 15 & 28 \\
\hline 10 & $46-50$ & 12 & 25 \\
\hline 11 & $50-55$ & 11 & 24 \\
\hline 12 & $56-60$ & 9 & 22 \\
\hline 13 & $>61$ & 7 & 23 \\
\hline & Total & $\mathbf{1 6 7}$ & $\mathbf{3 4 1}$ \\
\hline
\end{tabular}

Berdasarkan data kependudukan RT 03/ RW 02 Sei. Jang Kota Tanjungpinang, diketahui bahwa penduduk RT 03/ RW 02 Sei. Jang Kota Tanjungpinang didominasi dengan lulusan pendidikan Sekolah Dasar. berikut dibawah ini adalah tabel status pendidikan penduduk RT 03/ RW 02 Sei. Jang Kota Tanjungpinang:

Tabel 2

Status Lulusan Pendidikan

\begin{tabular}{|c|c|c|}
\hline No & Status & Jumlah (Jiwa) \\
\hline 1 & SD & 71 \\
\hline 2 & SMP & 83 \\
\hline 3 & SMA & 137 \\
\hline 4 & AKADEMI & 33 \\
\hline 5 & SARJANA (S1) & 69 \\
\hline
\end{tabular}

Berdasarkan data kependudukan RT 03/ RW 02 Sei. Jang Kota Tanjungpinang, dapat diketahui bahwapenduduk RT 03/ RW 02 Sei. Jang Kota Tanjungpinang didominasi oleh karyawan swasta. berikut ini adalah tabel status mata pencaharian penduduk RT 03/ RW 02 Sei. Jang Kota Tanjungpinang: 
Tabel 3

Status Mata Pencaharian Penduduk

\begin{tabular}{|c|c|c|}
\hline No & Status & Jumlah (Jiwa) \\
\hline 1 & PNS & 10 \\
\hline 2 & UMKM & 3 \\
\hline 3 & Rumah Kos & 5 \\
\hline 4 & Warung & 2 \\
\hline 5 & Gudang Kayu & 23 \\
\hline 6 & Dokter & 3 \\
\hline 7 & Karyawan Swasta & 71 \\
\hline
\end{tabular}

Analisis Hasil Pelaksanaan Kegiatan Pengabdian:

Pertama: Pendataan Penduduk, Kedua, Edukasi Pencegahan Penularan Covid-19, ketiga, Pemasaran produk melalui Platform Digital dan Keempat, Pembelajaran Agama melalui daring.

\section{Pendataan Penduduk}

Pendataan penduduk, yang dimaksud adalah dalam Upaya Pencegahan Covid-19 di RT 03/RW 02 Sei Jang Kota Tanjungpinang, Pelaksanakan kegiatan Kuliah Kerja Nyata (KKN) di RT 03/ RW 02 Sei Jang Kota Tanjungpinang terbagi menjadi dua tahapan yaitu:

1. Melakukan pendataan penduduk berdasarkan usia, pekerjaan, tingkat pendidikan, dan lain sebagainya. Kegiatan pendataan penduduk dilakukan melalui dokumen dari ketua RT. Dukomen tersebut berupa Kartu Keluarga (KK) penduduk RT tersebut. Melalui dokumen tersebut, penulis melakukan pengelompokan data berdasarkan jenis kelamin, umur, pekerjaan, serta jenjang pendidikan.

2. Melakukan pendataan penduduk yang keluar-masuk di wilayah RT 03/RW 02 Sei. Jang Kota Tanjungpinang. Pendataan ini lakukan guna untuk mengetahui seberapa banyak penduduk yang keluarmasuk wilayah di masa pandemi Covid-19 pada saat ini. Dengan begitu juga bisa diketahui kepedulian masyarakat dalam memutuskan rantai penyebaran Covid-19.

Dalam melakukan kegiatan pendataan penduduk di RT 03/RW 03 Sei. Jang Kota Tanjungpinang penulis mengalami kendala dalam melaksanakannya, kendala-kendala tersebut seperti: ketua RT memiliki kesibukan di luar tugasnya sebagai seorang RT, karena Selain sebagai ketua RT beliau juga sebagai ketua remaja masjid. Sehingga kadang jadwal yang telah ditetapkan untuk melakukan wawancara harus diundurkan di hari lainnya. Untuk itu, sebelum melakukan terjun kelapangan penulis melakukan kemunikasi terlebih dahulu kepada ketua RT melalui media WhatsApp. Selain itu, dalam pengumpulan dokumen masyarakat juga memiliki kendala, karena penduduk yang memiliki kartu keluarga (KK) di RT 03/RW 02 Sei. Jang Kota Tanjungpinang bertempat tinggal diluar wilayah RT tersebut. Sehingga penulis harus menunggu beberapa hari untuk mendapatkan dokumen yang diinginkan agar bisa melakukan pendataan.

Dari hasil pendataan penduduk, diperoleh data penduduk yang melakukan aktivitas keluar dan masuk pada RT 03/RW 02 Sei Jang ini adalah dalam bentuk tabel sebagai berikut:

Tabel 4

Data Penduduk Keluar-Masuk Wilayah RT 03/RW 02 Sei Jang Kota Tanjungpinang

\begin{tabular}{|c|c|c|c|}
\hline Hari & Tanggal & Jumlah (Jiwa) & Ket \\
\hline Jumat & 18 September 2020 & 23 & Menggunakan masker dan Handsenitizer \\
\hline Sabtu & 19 September 2020 & 17 & Menggunakan masker dan Handsenitizer \\
\hline Minggu & 20 September 2020 & 11 & Menggunakan masker dan Handsenitizer \\
\hline
\end{tabular}




\begin{tabular}{|c|c|c|c|}
\hline Senin & 21 September 2020 & 22 & Menggunakan masker dan Handsenitizer \\
\hline Selasa & 22 September 2020 & 25 & Menggunakan masker dan Handsenitizer \\
\hline Rabu & 23 September 2020 & 20 & Menggunakan masker dan Handsenitizer \\
\hline Kamis & 24 September 2020 & 27 & Menggunakan masker dan Handsenitizer \\
\hline Jumat & 25 September 2020 & 19 & Menggunakan masker dan Handsenitizer \\
\hline Sabtu & 26 September 2020 & 9 & Menggunakan masker dan Handsenitizer \\
\hline Minggu & 27 September 2020 & 5 & Menggunakan masker dan Handsenitizer \\
\hline Senin & 28 September 2020 & 24 & Menggunakan masker dan Handsenitizer \\
\hline Selasa & 29 September 2020 & 26 & Menggunakan masker dan Handsenitizer \\
\hline Rabu & 30 September 2020 & 23 & Menggunakan masker dan Handsenitizer \\
\hline Kamis & 1 Oktober 2020 & 21 & Menggunakan masker dan Handsenitizer \\
\hline Jumat & 2 Oktober 2020 & 22 & Menggunakan masker dan Handsenitizer \\
\hline Sabtu & 3 Oktober 2020 & 15 & Menggunakan masker dan Handsenitizer \\
\hline Minggu & 4 Oktober 2020 & 18 & Menggunakan masker dan Handsenitizer \\
\hline Senin & 5 Oktober 2020 & 22 & Menggunakan masker dan Handsenitizer \\
\hline Selasa & 6 Oktober 2020 & 25 & Menggunakan masker dan Handsenitizer \\
\hline Rabu & 7 Oktober 2020 & 20 & Menggunakan masker dan Handsenitizer \\
\hline Kamis & 8 Oktober 2020 & 27 & Menggunakan masker dan Handsenitizer \\
\hline Jumat & 9 Oktober 2020 & 19 & Menggunakan masker dan Handsenitizer \\
\hline Sabtu & 10 Oktober 2020 & 9 & Menggunakan masker dan Handsenitizer \\
\hline Minggu & 11 Oktober 2020 & 5 & Menggunakan masker dan Handsenitizer \\
\hline Senin & 12 Oktober 2020 & 24 & Menggunakan masker dan Handsenitizer \\
\hline Selasa & 13 Oktober 2020 & 26 & Menggunakan masker dan Handsenitizer \\
\hline Rabu & 14 Oktober 2020 & 23 & Menggunakan masker dan Handsenitizer \\
\hline Kamis & 15 Oktober 2020 & 21 & Menggunakan masker dan Handsenitizer \\
\hline Jumat & 16 Oktober 2020 & 23 & Menggunakan masker dan Handsenitizer \\
\hline Sabtu & 17 Oktober 2020 & 17 & Menggunakan masker dan Handsenitizer \\
\hline Minggu & 18 Oktober 2020 & 11 & Menggunakan masker dan Handsenitizer \\
\hline Senin & 19 Oktober 2020 & 22 & Menggunakan masker dan Handsenitizer \\
\hline Selasa & 20 Oktober 2020 & 25 & Menggunakan masker dan Handsenitizer \\
\hline Rabu & 21 Oktober 2020 & 20 & Menggunakan masker dan Handsenitizer \\
\hline Kamis & 22 Oktober 2020 & 27 & Menggunakan masker dan Handsenitizer \\
\hline Jumat & 23 Oktober 2020 & 19 & Menggunakan masker dan Handsenitizer \\
\hline \multicolumn{2}{|r|}{ Total } & 712 & \\
\hline
\end{tabular}

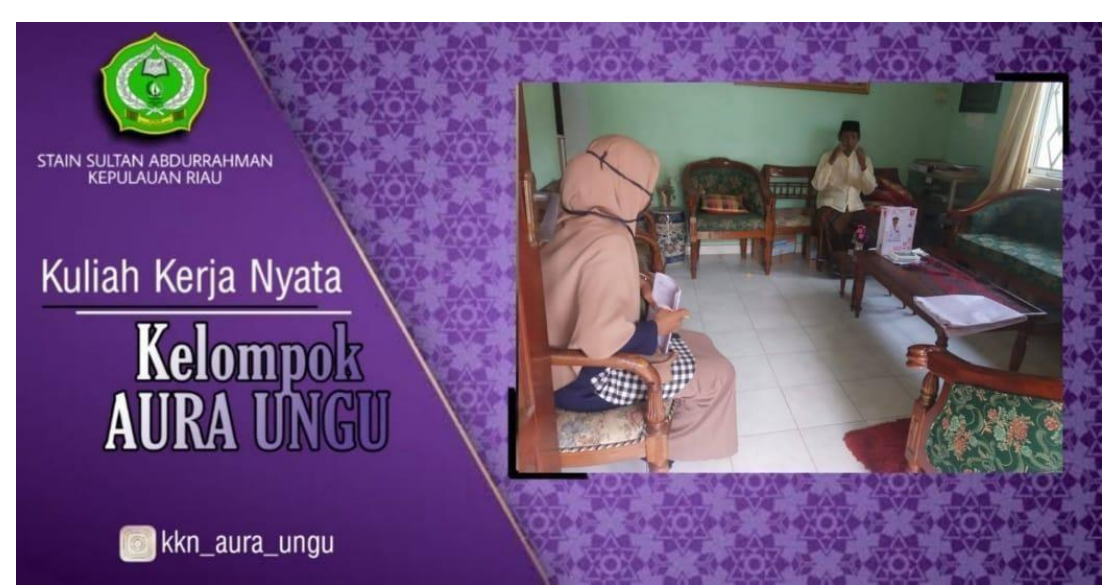

Gambar 1. Wawancara Pendataan Penduduk Kepada Ketua RT 03/ RW 02

Sei Jang Kota Tanjungpinang 
Berdasarkan hasil pendataan tersebut dapat dilakukan analisis beberapa hal sebagai berikut:

1. Kondisi RT 03/ RW 02 Sei. Jang Kota Tanjungpinang adalah salah satu wilayah yang cukup padat lalu lintas aktivitas keluar-masuk ke daerah tersebut, karena wilayah ini merupakan pusat perkotaan dan interaksi dengan masyarakat luar tidak dapat dibatasi.

2. Di dalam kondisi tersebut, diperlukan, tingkat kedisiplinan yang cukup tinggi tentang pemberlakukan protokol kesehatan kepada masyarakat yang akan memasuki wilayah tersebut. Oleh karena itu diperlukan upaya-upaya edukasi tentang pentingnya penerapan protokol kesehatan, melalui spanduk-spanduk di wilayah tersebut, dan fasilitas kebersihan di area-area umum seperti tempat cuci tangan dan pembagian masker gratis.

\section{Edukasi Pencegahan Penularan Covid-19}

Kegiatan selanjutnya adalah Edukasi pencegahan penularan Covid-19 di laksanakan di dua fokus lokasi yaitu sebagai berikut:

1. Melakukan edukasi pencegahan penularan melalui spanduk serta video yang disebarkan melalui media sosial sebagai himbauan dan anjuran pencegahan Covid-19 di RT 03 / RW 02 Sei Jang Kota Tanjungpinang.

Dalam pelaksanaan program kegiatan, dengan adanya keterbatasan aktivitas sosial pada masa pandemi covid-19, perencanaan dilaksanakan dengan menghindari kegiatan mengumpulkan masyarakat, guna mencegah penularan covid-19. Dengan kondisi tersebut peserta program pengabdian berusaha untuk dapat memberikan edukasi kepada masyarakat tentunya sesuai dengan juknis KKN di masa pandemi yang telah ditetapkan, tanpa harus membuat kerumunan masa. Adapunkegiatan yang telah dilaksanakan adalah sebagai berikut:

Pertama, Edukasi Tentang Penerapan Physical Distancing kepada masyarakat, dengan memberikan pemahaman melalui poster yang dibuat sesuai dengan anjuran dari pemerintah. Pada saat melakukan program kerja KKN KS masih terdapat masyarakat yang belum mengerti tentang pentingnya menjaga jarak dan tidak berkerumun, tentunya program kerja yang dilaksanakan ini bertujuan untuk memberantas mata rantai penyebaran covid-19.

Kedua, Edukasi Tentang 5 Langkah yang baik dan benar dalam mencuci tangan serta membiasakan diri untuk mencuci tangan, hal ini dilakukan karena penyebaran covid-19 ini dapat terjadi lewat sentuhan tangan, dalam rangka untuk mengantisipasi hal tersebut kebiasaan ini perlu di terapkan dalam keseharian, baik di rumah maupun pada ruang publik.

Ketiga, Edukasi dan Pembagian Masker kepada masyarakat RT 03/ RW 02 Sei. Jang Tanjungpinang, pada saat pelaksanaan masih didapati masyarakat yang tidak taat akan peraturan dari pemerintah yakni menggunakan masker ketika di luar rumah maupun dalam ruang publik, dalam kegiatan yang mendapatkan respon positif ini penulis melakukan edukasi di tempat ibadah yakni masjid dan ketika kegiatan gotong royong bersama dengan masyarakat setempat.

Keempat, Pelaksanaan program kerja tersebut juga telah disebarkan melalui media digital seperti whatsapp, instagram dan youtube. Tujuannya ialah agar pengedukasian menjadi lebih efektif serta menyeluruh, pada saat ini pengguna media sosial sangat banyak, tidak dipungkiri mulai dari anak-anak sampai orang tua. 


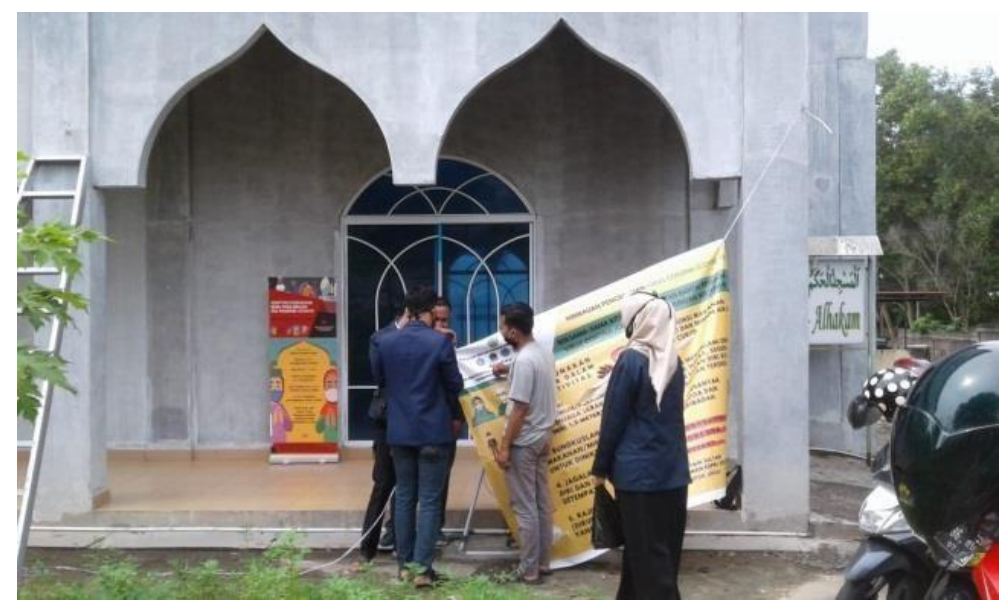

Gambar 2. Pemasangan Spanduk Pencegahan Covid-19

Beberapa spanduk Edukasi Pencegahan Covid-19 dapat dilihat di Media Sosial Intagram: @kknaura-ungu dan beberapa pada sosial media pribadi di instagram: @ ranazharas@ @ 04desinurmawatii, @immnr.a, @erlanggawaesaputra, @sanisahke.o dan beberapa akun lainnya. Adapun video Edukasi Pencegahan Covid-19 di akun channel youtube: (https://youtu.be/8UBSQn4NtOA).

2. Edukasi Pencegahan Covid-19 yang dilaksanakan di lokasi di Perumahan Bumi Air Raja Permai, Tanjungpinang.

Kegiatan ini menggunakan kategori KKN-DR yang telah dilaksanakan dengan pembuatan pamflet dan video edukasi tentang makanan bervitamin dan bergizi bertujuan untuk meningkatkan imunitas masyarakat pada masa pandemi seperti saat ini. Dengan terlaksananya program ini, maka pengetahuan masyarakat akan meningkat dan masyarakat lebih menyadari bahwa tidak hanya menjaga dari dalam, namun kita juga harus mampu menjaga tubuh dari dalam. Namun juga terdapat kendalakendala yang dihadapi dalam pelaksaan program ini sehingga program tidak berjalan secara optimal. Contoh permasalahan yang dihadapi salah satunya yaitu pada masyarakat dengan usia dewasa keatas, dimana dalam rentang usia tersebut, pada umumnya masyarakat kurang dapat memahami cara penggunaan media social, namun edukasi tetap dapat terlaksana dengan adanya brosur dan pamflet.

Dengan kegiatan yang bersifat edukasi seperti ini diharapkan masyarakat akan lebih memahami pentingnya menerapkan protokol kesehatan dalam kehidupan sehari-hari, sifat edukasi yang penulis berikan kepada masyarakat yakni 1. Edukasi penerapan physical distancing 2. Edukasi keharusan untuk mencuci tangan dan cara mencuci tangan yang benar 3. Edukasi untuk menggunakan masker di ruang publik dan tempat-tempat umum lainnya, upaya-upaya tersebut ditujukan untuk membantu pemerintah dalam mengurangi penyebaran covid-19 di Tanjungpinang. Kegiatan program kerja yang dilakukan oeh mahasiswa sesuai dengan hasil yang diharapkan yaitu masyarakat dapat meningkatkan pola hidup bersih dan sehat sehingga masyarakat dan anak-anak mampu menerapkan protokol kesehatan yang telah ditetapkan oleh pemerintah.

Adapun hasil yang didapatkan dari program ini yaitu meningkatnya pemahaman masyarakat tentang menjaga diri dari dalam dengan meningkatkan imunitas, respon yang diberi masyarakat juga baik sesuai dengan komentar-komentar positif yang masyarakat beri melalui whatsapp grup yang penulis buat dan melalui komentar-komentar yang diberikan di sosial media penulis. 


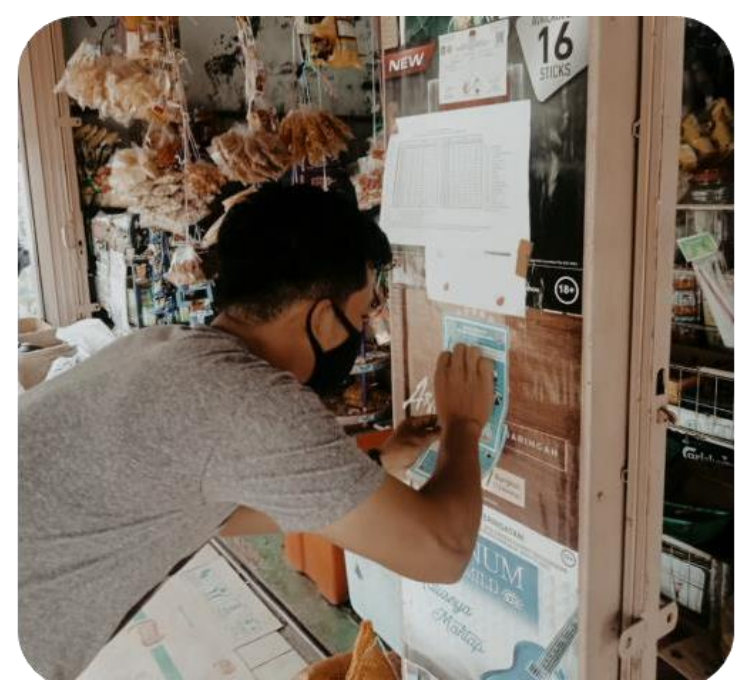

Gambar 3. Pemasangan Pamflet Edukasi Pencegahan Covid-19 di Perum Bumi Air Raja

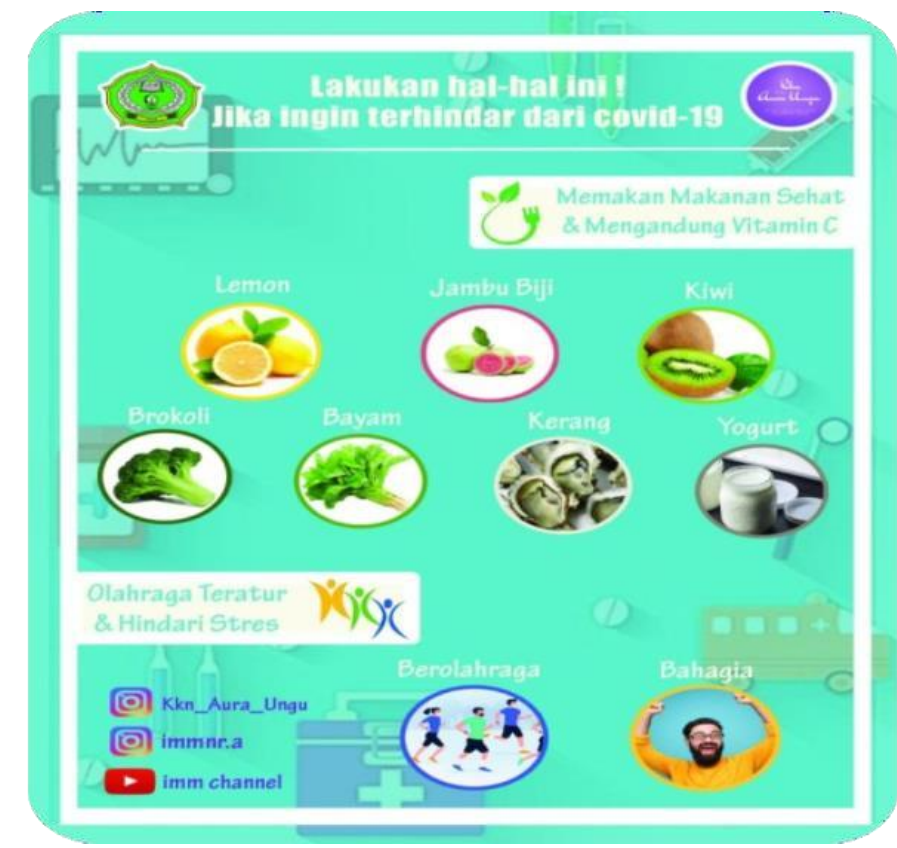

Gambar 4. Edukasi Pencegahan Covid-19 melalui media sosial

\section{Mengatasi Penurunan Penghasilan Usaha Mikro Kecil Menggunakan Strategi Pemasaran dengan Memanfaatkan Sosial Media di RT 03 RW 02 Sei Kang Kota Tanjungpinang}

UMKM di RT 03/RW 02 Sei Jang, yang mengalami penurunan pemasukan di bidang ekonomi dikarenakan masa pandemi covid-19 yang mengharuskan mereka tidak bekerja dan tetap di rumah saja, dan para pelanggan yang ikut mengikuti peraturan pemerintah untuk menghidari kerumunan dan beraktifitas di luar. Pemecahan masalah yang dilakukan pada saat melaksanakan pengabdian, peserta melaksanakan kategori KKN KS yaitu dengan memberikan penjelasan mengenai strategi penjualan dengan menggunakan sosial media untuk memperbaiki penurunan penghasilan. 
Langkah yang dilakukan ialah membuat video mengenai alternatif cara penjualan menggunakan penjualan di sosal media, yaitu dengan membuat video tutorial cara menggunakan sosial media untuk pemasaran yang diupload ke media sosial seperti youtube. Adapun kegiatan yang telah direncanakan dan dilaksanakan ialah:

1. Mewawancarai salah satu pemilik UMKM dengan penghasilan yang ia dapat disaat masa pandemi covid seperti saat ini

2. Membuat video cara memasarkan penjualan dengan menggunaakan sosial media. Penulis membuat video tersebut agar UMKM di RT 03/RW 02 bisa mengakses dan menonton video tersebut dan bisamelakukan nya untuk pemasaran penjualannanya.

Membantu membuat jualan salah satu UMKM di RT 03/RW 02 Sei Jang seperti pembuatan kue bingka dan membantu memasrkan penjualan mereka ke sosial media pribadi penulis.

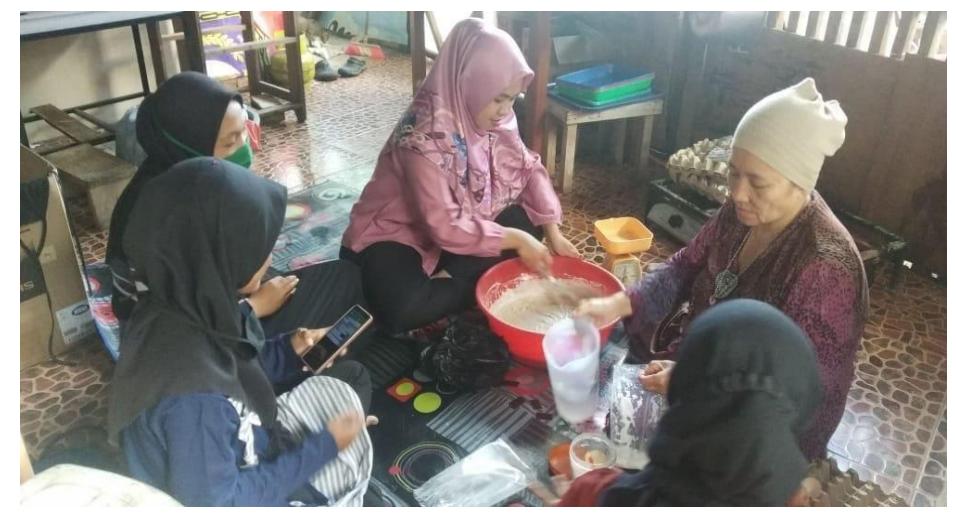

Gambar 5, Membantu UMKM Produksi pembuatan kue Bingka

Beberapa dokumentasi kegiatan dapat dilihat di Media Sosial Intagram: @kkn-aura-ungu dan beberapa pada sosial media pribadi di instagram: @04desinurmawatii, dan melaui akun youtube: Desi Nurmawati dan pada link youtube berikut ini: https://youtu.be/QvkhzXGZa3E.

\section{Pembelajaran Agama melalui daring}

Pendidikan menjadi bagian yang juga paling terdampak oleh Pandemi Covid-19 ini, pembelajaran yang awalnya dapat dilaksanakan secara langsung tatap muka, harus dganti dengan oembelajaran daring, begitu juga dalam pembelajaran di TPQ. Kegiatan pengabdian ini, dilaksanakan dengan tema Pemanfaatan media sosial dalam pembelajaran sejarah Nabi Muhammad SAW di TPQ Al-Amin. TPQ ini berlokasi di Wilayah Kota Tanjung Pinang, Kec. Bukit Bestari, Kelurahan Sei Jang, RT 04/RW 02, berdiri sejak tahun 2007. TPQ ini dibangun dengan tujuan agar anak-anak belajar Iqro' dan al-Qur'an serta bisa faham dalam hal agama.

Dalam pelaksanaan kegiatan KKN di TPQ AL-AMIN, banyak pelajaran dan pengalaman yang bisa diambil oleh penulis yaitu, bagaimana mengaplikasikan ilmu yang dipelajari di kampus kepada masyarakat, kegiatan KKN memberikan kesempatan kepada para mahasiswa untuk terampil dan produktif, walaupun dalam kondisi pandemi covid-19 ini. Melalui kegiatan KKN membentuk penulis menjadi lebih dewasa, baik dalam berpikir, bertingkah laku, bergaul, maupun disiplin, dan sebagai calon sarjana tenaga kependidikan kegiatan KKN menjadikan penulis sebagai calon sumber daya manusia yang siap dipakai, baik di instansi lembaga pendidikan maupun di lingkungan masyarakat, serta kegiatan KKN menyadarkan penulis bahwa prodi Ilmu al-Qur'an dan Tafsir tak hanya bergelut pada sektor agama saja, melainkan sektor lainnya sesuai dengan kebutuhan Masyarakat. 
Dalam melaksanakan program KKN DR ini penulis melakukan 3 tahapan perencanaan, yaitu perencanaan, pelaksanaan dan evaluasi. Pada tahap awal, penulis melakukan tahap perencanan. Pada tahap ini penulis mencari mitra dampingan selama KKN di TPQ Al-Amin, yakni RT 04 RW 02. Sekaligus penulis meminta izin untuk mengajar dan mengupload video untuk menambah wawasan potensi keilmuan melalui media sosial. Kemudian penulis mulai merencanakan pembuatan konsep video untuk Pembelajaran yang ada di TPQ Al-Amin, tahapan mencari mitra damping ini di lakukan pada tanggal 18 september 2020.

Selanjutnya pada tahap kedua penulis melakukan tahap pelaksanaan. Pada tahap ini penulis mulai membuat konten video dan foto yakni tahap shooting dan editing video, yang kemudian diupload ke media sosial untuk menambahkan wawasan keilmuan. Sebelum melaksanakan perekaman, terlebih dahulu disiapkan materi yang berkaitan dengan video yang akan dibuat yaitu Materi yang akan dijadikan bahan materi, pencarian materi yang akan diupload ke media sosial, hingga selesai. Tahapan ini dilakukan dalam beberapa tahapan waktu, yakni pengambilan shooting video dilakukan pada setiap minggu 1 kali, sembari melihat Materi yang akan diberikan nanti kepada santri TPQ.

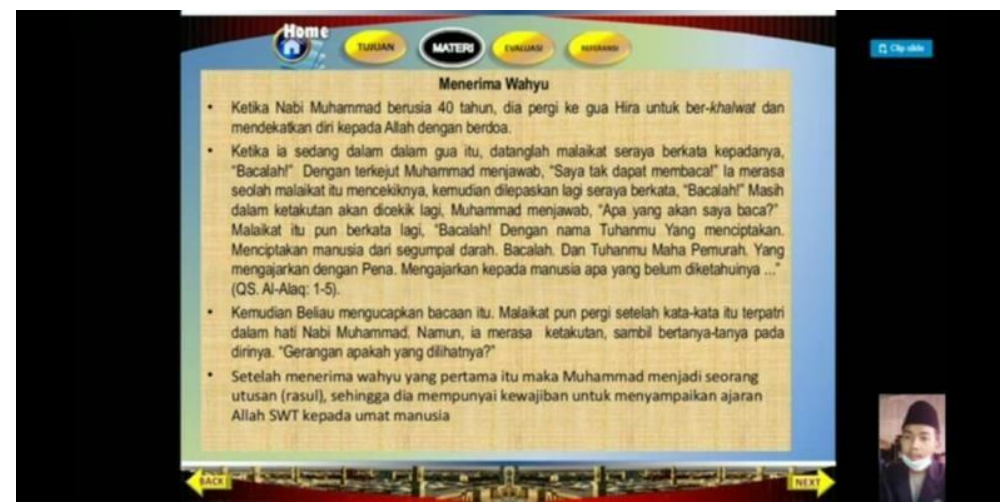

Gambar 6. Proses pembuatan video

Pada tahap terakhir penulis melakukan evaluasi. Pada tahapan ini, evaluasi dilakukan dengan cara Mengupload Ke Youtube. Tujuan dilaksanakannya evaluasi ini yaitu untuk menambah wawasan keilmuan santri TPQ.

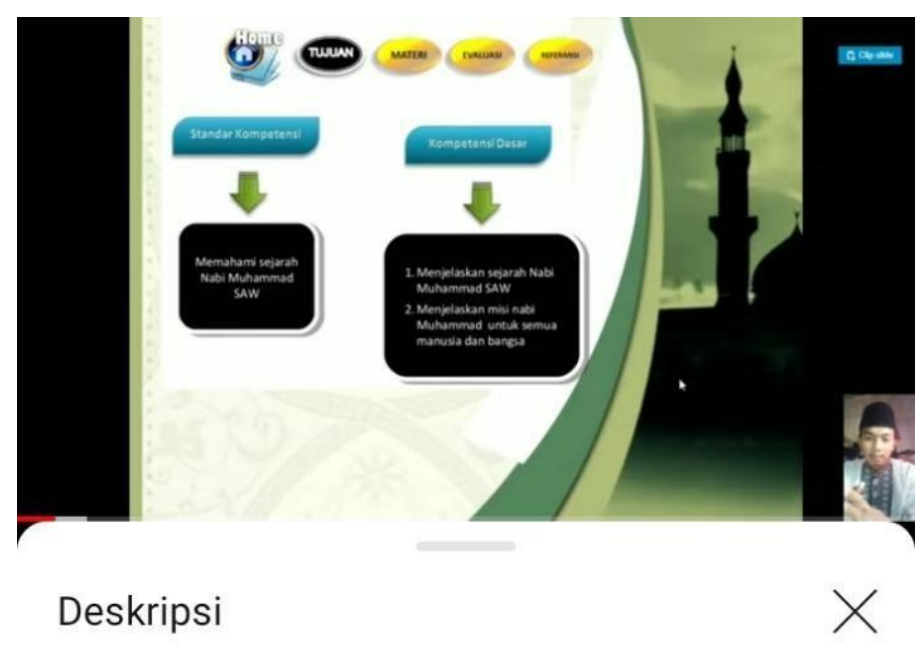

Sejarah Nabi Muhammad SAW

Muhammad kurnia Hafis · 31 x ditonton · 12 Okt 2020

Gambar 7. Publikasi melalui media sosial YouTube 
Selama melaksanakan program di TPQ Al-AMIN, Penulis telah berhasil menjalankan program dengan baik dan lancar. Dengan adanya program kegiatan penulis yakni berupa konten video yang memaparkan Penambahan Ilmu Pengatahuan Tentang Sejarah Nabi Muhammad SAW melalui media sosial instagram dan youtube, yakni di akun media sosial youtube channel dan instagram KKN Milik Akun Pribadi. Hal ini memberikan manfaat bagi Santri TPQ Khususnya Masyarakat awam dan masyarakat Sekitar RT 04 RW 02, yang mana bagi masyarakat hal ini menambah wawasan keilmuan bagi anak anak TPQ khususnya Masyarakat yang beragama Muslim.

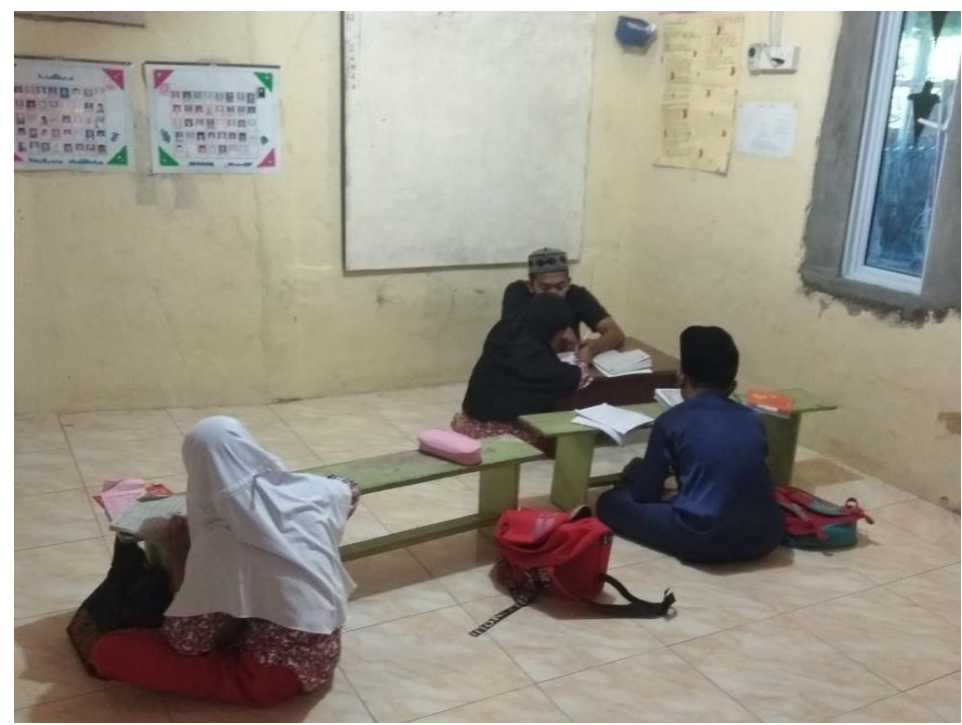

Gambar 8. Kegiatan Ngajar Mengajar Di TPQ

Dari respon yang diberikan pihak TPQ dan Ketua RT 04 memberikan respon yang positif dan mereka mendukung kegiatan yang saya lakukan di TPQ AL-Amin serta mengapresiasi dan bersedia untuk meneruskan penambahan wawasan keilmuan dalam media online. Dibandingkan dengan sebelumnya, sesuai pengamatan penulis terjadi peningkatan yang sangat baik, salah satunya adalah kesadaran orang tua atau wali yang mana kurangnya waktu untuk anak-anak belajar dalam keagamaan khususnya dalam situasi Covid-19, yang mana sekolah libur Panjang dan anak anak kurang waktu untuk belajar dan banyak waktu bermain HP di rumah.

Dalam hal ini penulis menyampaikan gagasan penulis kepada $\mathrm{rt}$ di antaranya adalah Diantaranya membuat pembelajaran online agar anak anak mudah belajar via online untuk menambah wawasan keilmuan selain yang penulis sampaikan.

Dikarenakan kurangnya waktu mengajar di TPQ atau waktu yang singkat yang mana sekali pertemuan hanya 1 jam saja dan waktu itu di gunakan hanya untuk mengaji saja dan belum cukup untuk menambah ilmu yang lainnya.

Oleh karena itu penulis menyampaikan kepada ketua TPQ dan RT agar membuat hal tersebut agar anak anak khususnya masyarakat awam bisa belajar lebih untuk mengatahui ilmu yang belum mereka ketahui dan bisa bertanya langsung lewat tatap muka yang sebentar dan menanyakan apa yang belum mereka pahami dari materi yang di berikan lewat media online. 


\section{Kesimpulan}

Berdasarkan hasil dan pembahasan dari kegiatan Pengabdian Kepada Masyarakat Berbasis Pogram KKN pada kondisi Pandemi Covid-19 tentang Analisis Pemberdayaan Masyarakat di masa pandemi Covid19 kepada masyarakat Kelurahan Sei Jang, Kota Tanjung Pinang, yang telah dilaksanakan dapat disimpulkan bahwa pandemi Covid-19 memberikan dampak yang signifikan terhadap kehidupan masyarakat Sei Jang. Adapun upaya pemberdayaan yang dilakukan meliputi tiga hal, yaitu Pertama: Pendataan Penduduk, Kedua, Edukasi Pencegahan Penularan Covid-19, ketiga, Pemasaran produk melalui Platform Digital dan Keempat, Pembelajaran Agama melalui daring.

\section{Saran}

Masyarakat Sei Jang secara umum, khususnya Pelaku UMKMnya dan anak didik di TPQ al-Amin, Sei Jang, Tanjung Pinang, dapat melaksanakan kegiatan sehari-hari dan usahanya menerapkan protokol kesehatan dan memulai melalukan adaptasi terhadap keadaan, serta upaya pencegahan dengan meningkatkan sistem imunitas tubuh dengan berolahraga dan bagi pelaku uusaha UMKM dapat melakukan inovasi pengembangan penjualan dalam masa pandemi Covid-19. Bagi Tim Peserta KKN STAIN Sultan Abdurrahman Kepulauan Riau, terutama kelompok Ungu, agar dapat melakukan evaluasi dan meningkatkan kualitas bentuk-bentuk program kerja sebagai upaya-upaya dalam membantu masyarakat. kemudian secara berkelanjutan tetap menjalin komunikasi dengan masyarakat apabila membutuhkan bantuan dalam bentuk kegiatan pengabdian.

\section{Ucapan Terimakasih}

Terimakasih kepada pihak-pihak yang telah mendukunng terlaksananya kegiatan pengabdian Kepada Masyarakat berupa KKN pada kondisi pandemi COVID-19 yaitu:

Ketua STAIN Sultan Abdurrahman Kepulauan Riau yang telah memberikan dukungan kepada tim pengabdian kepada masyarakat, KKN Covid-19.

Pusat Penelitian dan Pengabdian Masyarakat (P3M) STAIN Sultan Abdurrahman Kepulauan Riau sebagai hosting program pengabdian ini.

Masyarakat Sei Jang, Tanjung Pinang yang telah bersedia meluangkan waktu untuk berpartisipasi dalam melakukan kegiatan pengabdian kepada masyarakat.

Dan pihak-pihak terkait lainnya yang tidak dapat kami sebutkan satu-persatu.

\section{Referensi}

Abu Ahmadi dkk., (2003), Ilmu Pendidikan. Jakarta: PT Rineka Cipta.

Bosaparis. (2019). Pendidikan Kesejahteraan Keluarga. 10(2). Singaraja: Universitas Pendidikan Ganesha

Buku Panduan KKN Dalam Masa Wabah Covid-19, Tahun 2020.

Mulyadi. (2003). Activity-Based Costing System (jilid 1 ,cet. Ke-6) Yogyakarta : UPP AMP YKP.

Pusat Penelitian Dan Pengabdian Kepada Masyarakat (P3M) Stain Sultan Abdurrahman Kepulauan Riau. 2020. Pedoman Pelaksanaan Kuliah Kerja Nyata (KKN) Dalam Masa Wabah Corona Virus Disease 2019 (Covid-19) Tahun 2020. 
Suppawittaya. P., Pakara. Y., and Pratchayapong. Y., (2020), Effects of Social Distancing, Self-Quarantine and Self-Isolation during the COVID-19 Pandemic on People's Well-Being and How to Cope with It, International Journal of Science and Healthcare Research, Vol.5.2, Page.12-20.

Tim Kemenkes, (2020), Pedoman Pencegahan Dan Pengendalian COVID-19, Dokumen Resmi, Dirjen Pencegahan Dan Pengendalian Pencegahan Penyakit, Revisi ke-2, Jakarta.

Tim Kementerian Keuangan RI, 2020, Siaran Pers Pemerintah Waspada Dampak Pandemi Covid-19 Terhadap Ekonomi Indonesia, ww.kemenkeu.go.id diakses 10 Juni 2020.

UU No. 20 Tahun 2003 tentang Sistem Pendidikan Nasional [10] pasal (3)

WHO. (2020), Penggunaan Rasional Alat Perlindungan Diri Untuk Penyakit Coronavirus (COVID-19) Dan Pertimbangan Jika Ketersediaan Sangat Terbatas, Panduan Sementara, WHO.

Winarno Surakhmad. (1979). Metodologi Pengajaran Nasional, Bandung: Jemmars

Sumber Internet:

https://www.liputan6.com/regional/read/4204917/begini-kronologi-kasus-positif-virus-corona-covid-19pertama-di-tanjung-pinang. Diakses 20 november 2020

https://zonakepri.com/tambah-11-kasus-konfirmasi-covid-19-di-tanjungpinang-10-kasus-akibat-kontak-erat/. Diakses 20 November 2020

Wikipedia. (2020). Pariwisata, (Online). Tersedia: http://id.wikipedia.org/wiki/Pariwisata (27 oktober 2020). 